\title{
PRIMEIRAS EXPERIÊNCIAS NO RESIDÊNCIA PEDAGÓGICA DA UFT/ARRAIAS: A INSERÇÃO DA MÚSICA NO ESPAÇO ESCOLAR CAMPESINO
}

First experiences in the Pedagogical Residence of UFT / Arraias: the insertion of music in the campese school space

Primeras experiencias en la Residencia Pedagógica de UFT / Arraias: la inserción de música en el espacio escolar campesino

Desafios

Artigo Original

Original Article Artículo Original

Aparecida de Jesus Soares Pereira*1, Maristela Firmino da Cunha Gomes ${ }^{2}$, Angela Gomes Rosário Santos $^{3}$, Erli Alves dos Santos ${ }^{4}$, Warlen Barbosa Celedonio ${ }^{5}$

1,2,3,4,5 Laboratório de Educação Musical, Curso de Licenciatura em Educação do Campo, Universidade Federal do Tocantins-UFT, Arraias -TO, Brasil.

*Correspondência: Curso de Licenciatura em Educação do Campo, Universidade Federal do Tocantins - UFT, Campus Professor Dr. Sérgio Jacintho Leonor, Av. Juraíldes de Sena e Abreu, Setor Buritizinho/ sala 10 - Bloco Bala, Arraias - Tocantins, Brasil.CEP:77.330-000.e-mails: cida.soares@uft.edu.br

Artigo recebido em 03/04/2020 aprovado em 09/04/2020 publicado em 16/04/2020.

\section{INTRODUÇÃO}

O presente trabalho tem como objetivo fazer um relato das experiências dos residentes participantes do Programa Residência Pedagógica (PRP), que é uma atividade de formação oferecida e financiada pela Coordenação de Aperfeiçoamento de Pessoal de Nível Superior (CAPES) em parceria com a Universidade Federal do Tocantins- Campus de Arraias, no Curso de Licenciatura em Educação do Campo - Códigos e Linguagens: Artes Visuais e Música, regularmente matriculados que tenham cursado o mínimo de 50\% do curso, a fim de proporcionar-lhes aperfeiçoamento na formação através de desenvolvimento de projetos que fortaleçam o campo da prática, conduzindo o licenciando a exercitar de forma ativa a relação entre teoria e prática profissional docente.

Dentre as atividades realizadas neste programa, podemos citar o Seminário do Residência Pedagógica, promovido e realizado no dia 15 de setembro de 2018, no auditório da UFT em Arraias para discutir a Base Nacional Comum Curricular BNCC, seus impactos e o processo de implantação desse documento na Educação Básica. A participação neste programa proporciona a acadêmicos $\mathrm{e}$ professores um momento de discussão e reflexão sobre a prática docente.

O PRP vem contribuir para o crescimento dos futuros professores, permitindo a oportunidade de participar na prática da realidade da escola, estando envolvidos nas discussões promovidas, além preparar os acadêmicos na elaboração do plano de atividades das aulas, projetos e a sistematização dos registros que, de forma significativa estão contribuindo para uma mudança de perspectivas dos alunos da Escola Estadual Girassol de Tempo Integral Agrícola David Aires França, escola esta que participa do RP selecionada pela Capes, e também, através do projeto Institucional e do Subprojeto "O Ensino de Música nas Escolas do Campo".

\section{METODOLOGIAS E MATERIAIS}

A metodologia de uma aula ou projeto, se refere aos encaminhamentos educativos que um 
professor utiliza com o objetivo de auxiliar seu aluno na produção do conhecimento e neste sentido, para a execução do subprojeto da RP, no qual estamos inseridos, foi definida a metodologia de oficinas, e a partir de reuniões e observações feitas pelos residentes acompanhados pela preceptora da referida escola campo, foi apresentada a proposta do programa e as ideias foram sendo ajustadas até chegar a uma definição de uma das oficinas intitulada: Oficina de Poesia e Gêneros Musicais.

A fim de obter um levantamento dos materiais que poderiam ser disponibilizados pela escola para execução das oficinas, realizou-se um levantamento e catalogação de todos os recursos musicais, didáticos e tecnológicos disponíveis.

\section{RESULTADOS E DISCUSSÃO}

Após a etapa de ambientação na Escola campo, onde foi feito o diagnóstico e análise do PPP da Escola, levantamento de materiais e elaboração do plano de atividades a serem desenvolvidas, segue-se para a etapa de imersão na Escola. Chegou a hora da regência! Esse foi o momento onde pôde-se notar que, na prática os professores não são apenas transmissores do conhecimento, mas também aprendem durante o processo de ensino-aprendizagem.

No decorrer do período dessa etapa, junto à equipe da Escola Estadual Girassol Agrícola David Aires França teve-se a oportunidade de participar de reuniões, organização de alguns eventos da escola para a comunidade escolar. Para o aperfeiçoamento das atividades realizou-se junto a preceptora reuniões coletivas mensais para estudos, troca de informações, preparação de material, planejamento e replanejamento das oficinas que foram e iam ser desenvolvidas na escola campo.

Devido as distâncias de percurso dos residentes com a escola campo, em algumas atividades, as mídias sociais contribuíram como parceiras na troca de informações, materiais didáticospedagógicos, pesquisa e elaboração de planejamentos e trabalhos científicos. Foi uma atividade que fortaleceu os relacionamentos interpessoais $\mathrm{e}$ proporcionou crescimento teórico-prático.

Todos esses desafios começaram a partir do Estágio Curricular Supervisionado, e seguiu durante o PRP, ambos oportunizaram um seguimento para o reconhecimento do território escolar e a prática educativa, permitindo aos futuros docentes, a aprendizagem de lidar ao mesmo tempo com a teoria e a prática, não ficando presos apenas a certos métodos e técnicas como enfatiza Lima e Pimenta (2006), ao afirmar que o estágio associado a pesquisa é a forma através do qual podemos nos preparar como futuros profissionais para o exercício da nossa função docente, servindo de fortificação da relação com o ambiente de trabalho, mantendo a relação com outros profissionais e com os alunos. Já Libâneo (2008), diz que as competências se referem a conhecimentos, habilidades e atitudes obtidas nas situações de trabalho, no confronto de experiências, no contexto do exercício profissional. Entretanto, ambas as afirmações trazem reflexões sobre competências e habilidades docentes, especificamente em se tratando dos participantes do RP.

No que se refere a atividade do Residência Pedagógica podemos afirmar que houve um crescimento cognitivo dos participantes. Pois para a realização das oficinas houve uma preparação contínua para lidar com os alunos, e estes receberam a proposta de uma forma atuante e comprometida. Os residentes algumas vezes tiveram que utilizar até mesmo a improvisação em algumas circunstâncias necessárias, buscando soluções e alternativas para situações inesperadas.

Nesse contexto, o processo de formação teórico-prático proporcionada pelo RP foi e está sendo 
fundamental para formar uma maior autonomia profissional destes discentes.

\section{CONCLUSÃO}

As experiências no RP oportunizaram deparar com vários tipos de situações e aprendizados através do contato com a escola. $\mathrm{O}$ ambiente escolar tem sido parceiro no processo de construção de conhecimento e as atividades didático-pedagógicas planejadas e realizadas garantem cada vez mais o aperfeiçoamento das habilidades para a futura atuação docente.

Em verificação como residentes na referida escola, no que diz respeito a construção do conhecimento como futuros docentes, nota-se que, as tendências e as preocupações constatadas na formação de professores proporcionam diferentes métodos de atuação, baseadas na individualidade de cada profissional no exercício da sua função.

Ainda, vale salientar que para se desenvolver a competência profissional requer enfrentar e refletir sobre os desafios que incluem experiências positivas e negativas, e a diversidade de contextos educativos. Neste aspecto, o sistema de internato da escola que atende tanto alunos como tem atendido também aos residentes como uma forma distinta e diferente de um modelo escolar, onde os alunos por estarem longe de casa têm se expressado com bastante emoção, fato este constado em uma das oficinas desenvolvidas onde o tema trabalhado tratava sobre a família na escola.

E com todo o trabalho realizado, percebe-se a necessidade de ter um diálogo permanente entre a Universidade e a Escola de Educação Básica, permitindo assim, uma reflexão profunda sobre a relação teoria-prática, contribuindo para fortificar uma docência compartilhada, e formação de redes, onde residentes (licenciandos), professores orientadores, professores preceptores, alunos, e comunidade escolar como um todo se ajudem com o objetivo de uma
Educação de qualidade e comprometida com a formação dos cidadãos.

\section{AGRADECIMENTOS}

Agradecimento à CAPES pelo incentivo financeiro e organizacional do programa, à UFT por tornar possível a realização do Programa Residência Pedagógica e pelo uso de laboratórios e/ou empréstimo de equipamentos, ao Curso de Licenciatura em Educação do Campo da UFT, à escola parceira e Secretaria Estadual de Educação.

Todos os autores declararam não haver qualquer potencial conflito de interesses referente a este artigo.

\section{REFERÊNCIAS}

LIBÂNEO, José Carlos. Organização e gestão da escola teoria e prática. José Carlos Libâneo. Organização e gestão da escola teoria e pratica. Goiânia - 2008 .

LIMA, Maria Socorro Lucena; PIMENTA, Selma Selma Garrido. Estágio e docência: diferentes concepções. Poíesis Pedagógica, v. 3, n. 3 e 4, p. 524, 2006.

SECRETARIA DE EDUCAÇÃO DO ESTADO DO TOCANTINS. Projeto Político Pedagógico da Escola Estadual Girassol de Tempo Integral Agrícola David Aires França, 2018. 